Braz J Med Biol Res, January 2012, Volume 45(1) 72-77

doi: 10.1590/S0100-879X2011007500160

MTP $-493 \mathrm{G} / \mathrm{T}$ gene polymorphism is associated with steatosis in hepatitis C-infected patients

E.R.F. Siqueira, C.P.M.S. Oliveira, M.L. Correa-Giannella, J.T. Stefano, A.M. Cavaleiro, M.A.H.Z. Fortes, M.T.C. Muniz, F.S. Silva, L.M.M.B. Pereira and F.J. Carrilho

The Brazilian Journal of Medical and Biological Research is partially financed by

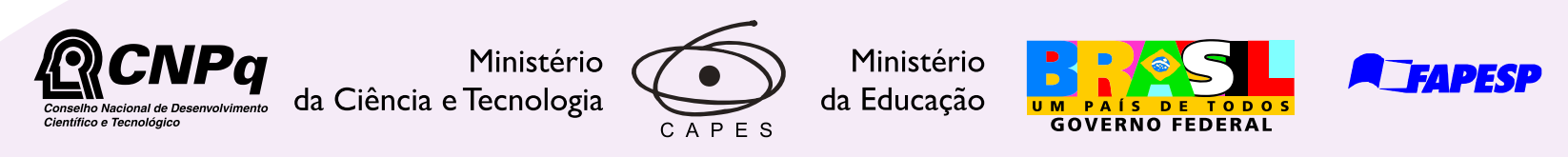
Institutional Sponsors
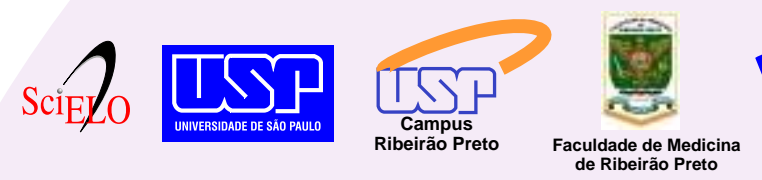

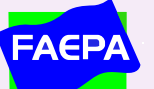
HCFMRP uldade de Medic

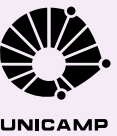
UNICAMP

$\theta$

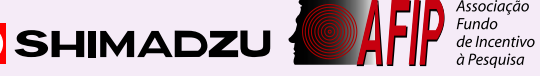

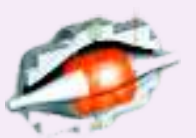

lore High - Performance MS Orbitrap Technology analitice Thermo 


\title{
MTP -493G/T gene polymorphism is associated with steatosis in hepatitis $\mathrm{C}$-infected patients
}

\author{
E.R.F. Siqueira ${ }^{1,3,4}$, C.P.M.S. Oliveira ${ }^{1}$, M.L. Correa-Giannella ${ }^{2}$, J.T. Stefano ${ }^{1}$, \\ A.M. Cavaleiro ${ }^{2}$, M.A.H.Z. Fortes ${ }^{2}$, M.T.C. Muniz ${ }^{3}$, F.S. Silva ${ }^{3}$, \\ L.M.M.B. Pereira ${ }^{4,5}$ and F.J. Carrilho ${ }^{1}$ \\ ${ }_{1}^{1}$ Departamento de Gastroenterologia, LIM-07, Faculdade de Medicina, Universidade de São Paulo, \\ São Paulo, SP, Brasil \\ ${ }^{2}$ Laboratório de Endocrinologia Celular e Molecular, LIM-25, Faculdade de Medicina, \\ Universidade de São Paulo, São Paulo, SP, Brasil \\ ${ }^{3}$ Departamento de Bioquímica, Faculdade de Medicina, Universidade de Pernambuco, Recife, PE, Brasil \\ ${ }^{4}$ Departamento de Gastroenterologia, Faculdade de Medicina, Universidade de Pernambuco, Recife, PE, Brasil \\ 5 Instituto do Fígado de Pernambuco, Recife, PE, Brasil
}

\begin{abstract}
The reduction of hepatic microsomal transfer protein (MTP) activity results in fatty liver, worsening hepatic steatosis and fibrosis in chronic hepatitis $\mathrm{C}(\mathrm{CHC})$. The $\mathrm{G}$ allele of the MTP gene promoter, $-493 \mathrm{G} / \mathrm{T}$, has been associated with lower transcriptional activity than the T allele. We investigated this association with metabolic and histological variables in patients with $\mathrm{CHC}$. A total of 174 untreated patients with $\mathrm{CHC}$ were genotyped for MTP $-493 \mathrm{G} / \mathrm{T}$ by direct sequencing using PCR. All patients were negative for markers of Wilson's disease, hemochromatosis and autoimmune diseases and had current and past daily alcohol intake lower than $100 \mathrm{~g} /$ week. The sample distribution was in Hardy-Weinberg equilibrium. Among subjects with genotype 1, 56.8\% of the patients with fibrosis grade $3+4$ presented at least one $\mathrm{G}$ allele versus $34.3 \%$ of the patients with fibrosis grade $1+2(O R$ $=1.8 ; 95 \% \mathrm{Cl}=1.3-2.3)$. Logistic regression analysis with steatosis as the dependent variable identified genotypes $\mathrm{GG}+\mathrm{GT}$ as independent protective factors against steatosis $(\mathrm{OR}=0.4,95 \% \mathrm{Cl}=0.2-0.8 ; \mathrm{P}=0.01)$. The results suggest that the presence of the $\mathrm{G}$ allele of MTP $-493 \mathrm{G} / \mathrm{T}$ associated with lower hepatic MTP expression protects against steatosis in our $\mathrm{CHC}$ patients.
\end{abstract}

Key words: Hepatitis C; Steatosis; Fibrosis; Microsomal transfer protein

\section{Introduction}

Hepatitis $\mathrm{C}$ virus (HCV) infects about $2-3 \%$ of the world population (1), leading to chronic hepatitis in up to $60-80 \%$ of infected individuals and is associated with liver steatosis, fibrosis and insulin resistance $(2,3)$.

Chronic hepatitis $\mathrm{C}(\mathrm{CHC})$ is characterized by inflammatory lesions in the liver and is now recognized as a systemic disease involving lipid metabolism, oxidative stress and mitochondrial function $(4,5)$. The liver damage observed during $\mathrm{CHC}$ consists mainly of inflammation, periportal necrosis and fibrosis. The onset and progression of fibrosis are the direct result of local inflammation that triggers stellate cell activation (6).

Both host and viral factors are implicated in the development of HCV-associated steatosis, but their contribution varies widely as a function of viral genotype. This is also supported by the observation that the degree of liver steatosis is directly related to the level of HCV replication as measured by serum HCV-RNA, at least in patients infected with HCV genotype 3 , in the absence of confounding metabolic causes of steatosis [type 2 diabetes, obesity or increased body mass index $(\mathrm{BMI})](7,8)$. However, there is strong evidence suggesting that some HCV proteins, particularly the structural capsid protein, core, and the non-structural protein, NS5A, can induce hepatic steatosis $(9,10)$.

Hepatic steatosis is a common histological feature of $\mathrm{CHC}$ and may contribute to fibrogenesis in this disease. The prevalence of steatosis in patients with $\mathrm{CHC}$ ranges from 40 to $86 \%$ as compared with rates of 20 to $30 \%$ reported in patients with other liver diseases $(11,12)$. The profibrogenic potential of steatosis is supported by several studies in which

Correspondence: C.P.M.S. Oliveira, Departamento de Gastroenterologia (LIM-07), FM, USP, Av. Dr. Arnaldo, 455, 3ํandar, 01246903 São Paulo, SP, Brasil. Fax: +55-11-3069-7830. E-mail: cpm@usp.br

Received June 29, 2011. Accepted November 25, 2011. Available online December 9, 2011. Published January 16, 2012. 
a link has been demonstrated between necroinflammatory activity and steatosis grade $(13,14)$.

It has been shown in cell lines that HCV core protein, which induces steatosis, also promotes oxidative stress $(15,16)$. The profibrogenic properties of oxidative stress are mediated by direct DNA and mitochondrial damage, induction of hepatocyte apoptosis, and amplification of the inflammatory response (17). Additionally, the HCV core protein and non-structural proteins are thought to induce steatosis by interfering with lipid synthesis $(18,19)$.

In transgenic mice, the HCV core protein inhibits microsomal triglyceride transfer protein (MTP) leading to accumulation of intrahepatic triglyceride (20). MTP is a heterodimeric lipid transfer protein present on the luminal side of the endoplasmic reticulum (ER) in the liver, intestine and heart $(21,22)$. Genetic polymorphisms can modulate the concentration of MTP in the ER and have an impact on the secretory pattern of lipoproteins (23). A common single nucleotide polymorphism (SNP) in the MTP gene promoter, $-493 \mathrm{G} / \mathrm{T}$, has been described as functional, with the $\mathrm{G}$ allele promoting less transcriptional activity than the $T$ allele $(24,25)$. Considering the possible interaction between MTP expression and $\mathrm{HCV}$ proteins, we investigated if genetic variations in the MTP gene could modulate metabolic and histological variables in patients with $\mathrm{CHC}$ from Brazil and we evaluated the MTP $-493 \mathrm{G} / \mathrm{T}$ SNP.

\section{Patients and Methods}

\section{Patients}

One hundred and seventy-four untreated patients with CHC (91 males and 83 females) presenting increased aminotransferase concentrations for at least 6 months and testing positive for anti-HCV antibodies (third-generation enzyme immunoassay) and for HCV-RNA(RT-PCR, Roche Cobas Amplicor 2.0, Roche Diagnostics, Switzerland) were enrolled between February 2007 and October 2009 at the Liver Institute of Pernambuco. The HCV genotype, determined by the line probe assay (LiPA) (Innolipa HCV II; Immunogenetics, Belgium), was 1 in 113 cases and non-1 in 61 cases.

This transverse study was conducted according to the Helsinki declaration of 1975. The protocol was approved by the Internal Review Board of Universidade de São Paulo and Universidade de Pernambuco and all subjects gave written informed consent to participate.

Other causes of liver disease were excluded by ultrasound studies of the hepatobiliary system, viral serology, measurements of autoantibody titers and of serum iron, ferritin and transferrin saturation, ceruloplasmin and copper concentrations, and alpha1-antitrypsin. Patients who had $\mathrm{a}>100 \mathrm{~g} /$ week alcohol intake determined by a detailed personal history, questioning of family members, and investigation of previous medical records, were excluded. Patients receiving immunosuppressive drugs or drugs causing steatosis (corticosteroids, antiepileptic agents, tamoxifen, and amiodarone) were also excluded.

MTP $-493 \mathrm{G} / \mathrm{T}$ SNP was analyzed in all patients, but plasma samples were collected from only 138 patients at the time of liver biopsy and used to determine total cholesterol, low-density lipoprotein cholesterol (LDL-C), high-density lipoprotein cholesterol (HDL-C), triglycerides (Tg), alanine aminotransferase (ALT), aspartate aminotransferase (AST), gamma-glutamyl transferase ( $\mathrm{G} T$ ), alkaline phosphatase (AP), fasting glucose and insulin concentrations, and homeostasis model assessment-insulin resistance (HOMA-IR): fasting insulin $(\mu \mathrm{U} / \mathrm{mL}) \times$ fasting glycemia (mM/22.5). Insulin resistance was considered to be present when HOMA-IR $\geq 2.5$, a value based on a previous study conducted on the Brazilian population (26).

\section{Laboratory assays}

Blood samples were centrifuged for $60 \mathrm{~min}$ to separate plasma, serum and leukocytes and stored at $-80^{\circ} \mathrm{C}$. Fasting glucose, total cholesterol and fractions, Tg, ALT, AST, AP, YGT, and insulin concentrations were measured by standard methods using automated techniques (Cobas, Roche). LDL$\mathrm{C}$ was determined by the Friedewald equation (27).

Genomic DNA was extracted from peripheral blood leukocytes by the salting-out method. The promoter region of the MTP gene was amplified by the polymerase chain reaction (PCR) using the following set of primers: forward 5'-CTCATACAGTTTCACACATAAGG-3', reverse 5'-CAAACTCTGCTAAACCTAACCAA-3' (which yielded a 200-bp PCR product). The -493G/T SNP of the MTP gene was determined by direct sequencing of the PCR products using ABI PRISM dGTP BigDy Terminator v3.0 Ready Reaction Cycle Sequencing (Applied Biosystems, USA) on an ABI PRISM 3130 XL Genetic Analyzer (Applied Biosystems).

\section{Histological analysis}

Liver tissue was fixed in $4 \%$ formaldehyde and processed for hematoxylin-eosin and Masson trichrome staining for histological analysis. A single experienced liver histopathologist who was blind to the patients' clinical data and HCV genotype carried out the histological assessments. Stages of fibrosis and grades of inflammation were scored according to METAVIR; F0 (no fibrosis), F1 (portal fibrosis without septa), F2 (portal fibrosis with few septa), F3 (numerous septa without cirrhosis), F4 (cirrhosis). Steatosis was graded $0-3$ based on the percent of hepatocytes harboring lipid droplets in the biopsy ( 0 = none; $1=1-33 \% ; 2=34-66 \%$, and 3 representing $>66 \%$ steatotic hepatocytes).

\section{Statistical analysis}

Data analysis was performed with the SPSS 15.0 software. Normal distribution of the groups was preliminarily evaluated by the Kolmogorov-Sminorv test. Differences between groups were assessed by analysis of variance (ANOVA) when variables were normally distributed. The 
chi-square test or the Fisher exact test was used to compare categorical variables. Logistic regression analysis was performed with steatosis and fibrosis as dependent variables. The Pearson test was used to analyze the model that was assumed for the MTP $-493 \mathrm{G} / \mathrm{T}$ polymorphism (only TT homozygosity confers a higher activity to the MTP promoter). Results were considered to be significant when the $\mathrm{P}$ value was $<0.05$.

\section{Results}

\section{Clinical and biochemical analysis}

Of the 174 patients studied, $52.3 \%(91 / 174)$ were males and $47.7 \%$ (83/174) were females. The biochemical characteristics according to genotype and histological classification were analyzed for 138 patients. The patients were stratified according to viral genotype [1 ( $\mathrm{N}=93)$ vs non-1 $(\mathrm{N}=45)$; Table 1], and according to histological grades of fibrosis $[1+2(\mathrm{~N}=101)$ vs $3+4(\mathrm{~N}=37)$; Table 2] and of steatosis [no steatosis $(\mathrm{N}=45)$ vs steatosis $(\mathrm{N}=93)$; Table 3].

The biochemical characteristics according to genotype classification demonstrated that the concentration of total cholesterol was the only variable significantly different between patients with genotype 1 and genotype non-1 (158.01 vs $138.58 \mathrm{mg} / \mathrm{dL}$, respectively; $\mathrm{P}=0.01$; Table 1). CHC patients with grade $3+4$ fibrosis presented higher concen-

Table 1. Clinical and biochemical characteristics of chronic hepatitis $\mathrm{C}$ patients according to genotype classification.

\begin{tabular}{lrc}
\hline & $\begin{array}{c}\text { Genotype } 1 \\
(\mathrm{~N}=93)\end{array}$ & $\begin{array}{c}\text { Genotype non-1 } \\
(\mathrm{N}=45)\end{array}$ \\
\hline Age & 54.06 & 51.59 \\
Fasting glucose & 92.58 & 100.13 \\
HOMA-IR & 2.72 & 3.35 \\
AST (U/L) & 68.69 & 73.24 \\
ALT (U/L) & 84.02 & 91.56 \\
YGT (U/L) & 86.06 & 84.31 \\
AP (U/L) & 83.03 & 72.67 \\
Total cholesterol (mg/dL) & 158.01 & $138.58^{*}$ \\
HDL-C (mg/dL) & 49.05 & 46.73 \\
LDL-C (mg/dL) & 88.00 & 74.44 \\
Triglycerides (mg/dL) & 105.89 & $91.69^{\star}$ \\
\hline
\end{tabular}

Reference values: glycemia $=<100 \mathrm{mg} / \mathrm{dL} ;$ HOMA-IR $=<2.5$; AST: males $=10-34 \mathrm{U} / \mathrm{L}$, females $=10-36 \mathrm{U} / \mathrm{L} ;$ ALT: males $=10-$ $44 \mathrm{U} / \mathrm{L}$, females $=10-36 \mathrm{U} / \mathrm{L} ; \mathrm{\gamma GT}$ : males $=11-50 \mathrm{U} / \mathrm{L}$, females = 7-32 U/L; AP: males = 45-122 U/L, females = 32-104 U/L; total cholesterol $=<200 \mathrm{mg} / \mathrm{dL} ; \mathrm{HDL}-\mathrm{C}=>40 \mathrm{mg} / \mathrm{dL}$; LDL-C $=<130$ $\mathrm{mg} / \mathrm{dL}$; triglycerides $=<150 \mathrm{mg} / \mathrm{dL}$. HOMA-IR $=$ homeostasis model assessment for insulin resistance; $A S T=$ aspartate aminotransferase; ALT = alanine aminotransferase; $\gamma \mathrm{GT}$ = gammaglutamyl transferase; $\mathrm{AP}=$ alkaline phosphatase; $\mathrm{HDL}-\mathrm{C}=$ highdensity lipoprotein cholesterol; LDL-C = low-density lipoprotein cholesterol. ${ }^{*} \mathrm{P}<0.05$ compared to genotype 1 (chi-square test). trations of AST (87.14 vs $63.96 \mathrm{U} / \mathrm{L} ; \mathrm{P}=0.01)$, ALT (105.7 vs $79.44 \mathrm{U} / \mathrm{L} ; \mathrm{P}=0.01)$ and $\mathrm{YGT}(120.92$ vs $72.51 \mathrm{U} / \mathrm{L} ; \mathrm{P}$ $=0.02$ ) than patients with fibrosis $1+2$ (Table 2$)$. The group of patients with steatosis presented lower concentrations of total cholesterol (146.24 vs $162.91 \mathrm{mg} / \mathrm{dL} ; \mathrm{P}=0.02)$, and of LDL-C (78.44 vs 94.18 mg/dL; P = 0.03; Table 3).

\section{MTP gene polymorphism}

The distribution of the $-493 \mathrm{G} / \mathrm{T}$ SNP genotypes was consistent with Hardy-Weinberg equilibrium. The genotype

Table 2. Clinical and biochemical characteristics of chronic hepatitis $\mathrm{C}$ patients according to fibrosis stage.

\begin{tabular}{lcc}
\hline & $\begin{array}{c}\text { Fibrosis 1+2 } \\
(\mathrm{N}=101)\end{array}$ & $\begin{array}{c}\text { Fibrosis 3+4 } \\
(\mathrm{N}=37)\end{array}$ \\
\hline Age & 52.26 & 55.07 \\
Fasting glucose & 92.81 & 101.14 \\
HOMA-IR & 2.73 & 3.47 \\
AST (U/L) & 63.96 & $87.14^{*}$ \\
ALT (U/L) & 79.44 & $105.70^{*}$ \\
YGT (U/L) & 72.51 & $120.92^{*}$ \\
AP (U/L) & 73.20 & 97.27 \\
Total cholesterol (mg/dL) & 152.63 & 149.05 \\
HDL-C (mg/dL) & 47.55 & 50.32 \\
LDL-C (mg/dL) & 85.01 & 79.65 \\
Triglycerides (mg/dL) & 101.32 & 101.11 \\
Frequency GG+GT (\%) & $39.7 \%(\mathrm{~N}=116)$ & $48.3 \%(\mathrm{~N}=58)$ \\
\hline
\end{tabular}

See Table 1 for reference values and explanation of abbreviations. ${ }^{*} \mathrm{P}<0.05$ compared to fibrosis $1+2$ (chi-square test).

Table 3. Clinical and biochemical characteristics of chronic hepatitis $\mathrm{C}$ patients according to steatosis grade.

\begin{tabular}{lcc}
\hline & $\begin{array}{c}\text { No steatosis } \\
(\mathrm{N}=45)\end{array}$ & $\begin{array}{c}\text { Steatosis } \\
(\mathrm{N}=93)\end{array}$ \\
\hline Age & 52.04 & 53.97 \\
Fasting glucose & 93.24 & 95.91 \\
HOMA-IR & 2.84 & 2.97 \\
AST (U/L) & 65.38 & 72.49 \\
ALT (U/L) & 79.44 & 89.88 \\
YGT (U/L) & 81.16 & 87.59 \\
AP (U/L) & 80.71 & 79.14 \\
Total cholesterol (mg/dL) & 162.91 & $146.24^{*}$ \\
HDL-C (mg/dL) & 50.16 & 47.40 \\
LDL-C (mg/dL) & 94.18 & $78.44^{*}$ \\
Triglycerides (mg/dL) & 95.09 & 104.25 \\
Frequency GG+GT (\%) & $50 \%(\mathrm{~N}=70)$ & $37.5 \%(\mathrm{~N}=104)$ \\
\hline
\end{tabular}

See Table 1 for reference values and explanation of abbreviations. ${ }^{*} \mathrm{P}<0.05$ compared to no steatosis (chi-square test). 
frequencies were analyzed for 174 patients grouped according to histological grades of fibrosis and steatosis: genotypes GG+GT occurred in $39.7 \%$ of the patients with $1+2$ fibrosis and in $48.3 \%$ of the patients with $3+4$ fibrosis $(P=0.05$; Table 2 ) and in $50 \%$ of the patients with no steatosis vs $37.5 \%$ of the patients with steatosis ( $P=0.12$; Table 3 ).

Among subjects infected with virus genotype 1,56.8\% of the patients with grade $3+4$ fibrosis presented at least one $\mathrm{G}$ allele vs $34.3 \%$ of the patients with grade $1+2$ fibrosis $(\mathrm{OR}=1.8 ; 95 \% \mathrm{Cl}=1.3-2.3)$. This association was not observed in patients infected with HCV non-1 genotypes (Table 4). Logistic regression analysis with $3+4$ fibrosis as a dependent variable in the whole population (HCV genotypes $1+$ non-1), however, did not identify the MTP genotype as a risk factor for the presence of fibrosis (Table 5).

Logistic regression analysis with steatosis as the dependent variable in the whole population (HCV genotypes $1+$ non-1) identified genotypes GG+GT as independent protective factors against steatosis $(\mathrm{OR}=0.4 ; 95 \% \mathrm{Cl}=$ 0.2-0.8; P = 0.01; Table 6).

\section{Discussion}

In this study, we set out to establish the role of the genetic MTP $-493 \mathrm{G} / \mathrm{T}$ SNP in the pathogenesis of steatosis and

Table 4. Allele frequencies of the MTP $-493 \mathrm{G} / \mathrm{T}$ polymorphism in chronic hepatitis $\mathrm{C}$ patients according to steatosis and fibrosis grades and according to viral genotypes.

\begin{tabular}{|c|c|c|c|c|}
\hline \multirow[t]{2}{*}{ MTP } & \multicolumn{2}{|c|}{ Genotype 1} & \multicolumn{2}{|c|}{ Genotype non-1 } \\
\hline & TT & $\mathrm{GT}+\mathrm{GG}$ & TT & $\mathrm{GT}+\mathrm{GG}$ \\
\hline Fibrosis $1+2$ & $50(65.7 \%)$ & $26(34.3 \%)^{*}$ & $20(50.0 \%)$ & $20(50.0 \%)$ \\
\hline Fibrosis $3+4$ & $16(43.2 \%)$ & $21(56.8 \%)$ & $14(66.6 \%)$ & $7(33.4 \%)$ \\
\hline No steatosis & $29(61.7 \%)$ & 18 (38.3\%) & $15(65.2 \%)$ & $8(34.8 \%)$ \\
\hline Steatosis & $37(56.0 \%)$ & $29(44.0 \%)$ & $19(50.0 \%)$ & $19(50.0 \%)$ \\
\hline
\end{tabular}

${ }^{*} \mathrm{P}<0.05$ compared to TT (Fisher exact test).

Table 5. Logistic regression analysis with fibrosis $3+4$ as the dependent variable.

\begin{tabular}{lll}
\hline Variables & OR & $95 \% \mathrm{Cl}$ \\
\hline Gender: F/M & 0.9 & $0.5-1.7$ \\
$\mathrm{HOMA} \geq 2.5$ & 0.8 & $0.4-1.8$ \\
LDL-C $\geq 130$ & 2.1 & $0.4-10.0$ \\
$\mathrm{HDL}-\mathrm{C} \leq 40$ & 1.0 & $0.4-2.3$ \\
Total cholesterol $\geq 200$ & 1.7 & $0.3-8.3$ \\
Triglycerides $\geq 150$ & 1.4 & $0.4-5.3$ \\
GG+GT (MTP) & 1.4 & $0.7-2.6$ \\
\hline
\end{tabular}

See Table 1 for reference values and explanation of abbreviations. There were no statistically significant effects (Fisher exact test). fibrosis in Brazilian patients with $\mathrm{CHC}$. Our data showed that the $\mathrm{G}$ allele was more frequently present in $\mathrm{CHC}$ patients infected with genotype 1 with higher degrees of fibrosis. Also, genotypes GG+GT were found to be independent protective factors against steatosis in the whole population of $\mathrm{CHC}$ patients (genotype $1+$ non-1).

The association of MTP $-493 \mathrm{G} / \mathrm{T}$ SNP with steatosis seems to differ between nonalcoholic fatty liver disease (NAFLD) and hepatitis C. While the T allele, associated with a higher MTP transcriptional activity, protects against the development of NAFLD by increasing Tg exportation from hepatocytes $(28,29)$, it has been associated with steatosis in $\mathrm{CHC}$ patients infected with genotype 3 probably by promoting the production of a more lipid-rich very lowdensity lipoprotein (VLDL) that facilitates maturation of HCV precursors by optimizing HCV replication, thus contributing to a higher degree of steatosis (30).

However, data regarding the association of MTP $-493 \mathrm{G} / \mathrm{T}$ SNP with histological variables in $\mathrm{CHC}$ patients are still conflicting. Initially, Richardson et al. (31) examined this polymorphism among a set of SNPs in eight genes previously associated with hepatic fibrosis in a group of 326 patients with $\mathrm{CHC}$ and identified homozygosity for either the $\mathrm{G}$ or the T allele of the $-493 \mathrm{G} / \mathrm{T}$ SNP as independent risk factors for more rapid progression of liver fibrosis. This finding is intriguing in view of evidence from functional studies that $G$ and $T$ alleles are associated with different transcriptional activities of the MTP gene.

Petit et al. (32), in a small series of 86 HCV-positive patients, 39 of them demonstrating signs of steatosis, did not find an association between the MTP $-493 \mathrm{G} / \mathrm{T}$ SNP and liver steatosis, while Zampino et al. (30) analyzed 102 patients infected with HCV genotype 3 and showed higher degrees of steatosis, higher serum levels of HCV-RNA and more advanced fibrosis in carriers of the MTP T allele. Also, Mirandola et al. (33) evaluated a cohort of $298 \mathrm{CHC}$ patients and found age, BMI, HCV genotype 3 and MTP T allele as independent risk factors for high grades of steatosis. Thus, the finding of the present study that genotypes GG+GT were

Table 6. Logistic regression analysis with steatosis as the dependent variable.

\begin{tabular}{lll}
\hline Variables & OR & $95 \% \mathrm{Cl}$ \\
\hline Gender: $F / M$ & 1.1 & $0.6-2.0$ \\
HOMA-IR $\geq 2.5$ & 1.5 & $0.7-3.2$ \\
LDL-C $\geq 130$ & 0.5 & $0.2-1.6$ \\
HDL-C $\leq 40$ & 1.1 & $0.5-2.4$ \\
Total cholesterol $\geq 200$ & 0.8 & $0.2-2.9$ \\
Triglycerides $\geq 150$ & 0.6 & $0.2-1.8$ \\
GG+GT (MTP) & 0.4 & $0.2-0.8^{*}$ \\
\hline
\end{tabular}

See Table 1 for reference values and explanation of abbreviations. ${ }^{*} \mathrm{P}<0.05$ for GG+GT (MTP) as a variable (Fisher exact test). 
independent protective factors against steatosis points in the same direction as the results published by the latter two authors, with the difference that, in the present series, the association between the SNP and steatosis was observed regardless of HCV genotype.

We observed lower concentrations of total serum cholesterol and LDL-C in CHC patients with steatosis. Similar results have been reported by Corey et al. (34), who demonstrated that serum lipids play a role in hepatitis $C$ virion circulation and hepatocyte entry. In a cohort of 179 patients with $\mathrm{CHC}$, these investigators compared the serum cholesterol, LDL-C, HDL-C and Tg in 180 age-matched controls and showed that patients with HCV had lower concentrations of total cholesterol and LDL-C than the control group. No difference in serum concentration of HDL-C and $\mathrm{Tg}$ was found between the two groups. Probably the lipo-viral particles use the LDL-C receptors of hepatocytes as points of entry of the virus. Once inside the hepatocyte, replication depends of the lipid environment of the host (35-37).

First, the severity of steatosis correlates with the level of HCV-RNA both in liver and in serum, especially in patients with genotype 3 . Second, the fatty liver may significantly decrease if not disappear altogether when patients are successfully treated with antiviral agents, especially patients

\section{References}

1. Alter MJ. Epidemiology of hepatitis $C$ in the West. Semin Liver Dis 1995; 15: 5-14.

2. Clément $S$, Pascarella S, Negro F. Hepatitis C virus infection: molecular pathways to steatosis, insulin resistance and oxidative stress. Viruses 2009; 1: 126-143.

3. Syed GH, Amako Y, Siddiqui A. Hepatitis C virus hijacks host lipid metabolism. Trends Endocrinol Metab 2010; 21: 33-40.

4. Moradpour D, Blum HE. Pathogenesis of hepatocellular carcinoma. Eur J Gastroenterol Hepatol 2005; 17: 477-483.

5. Zoulim F, Chevallier M, Maynard M, Trepo C. Clinical consequences of hepatitis C virus infection. Rev Med Virol 2003; 13: $57-68$.

6. Romero-Gomez M, Castellano-Megias VM, Grande L, Irles JA, Cruz M, Nogales MC, et al. Serum leptin levels correlate with hepatic steatosis in chronic hepatitis C. Am J Gastroenterol 2003; 98: 1135-1141.

7. Adinolfi LE, Gambardella M, Andreana A, Tripodi MF, Utili R, Ruggiero $G$. Steatosis accelerates the progression of liver damage of chronic hepatitis $\mathrm{C}$ patients and correlates with specific HCV genotype and visceral obesity. Hepatology 2001; 33: 1358-1364.

8. Rubbia-Brandt L, Quadri R, Abid K, Giostra E, Male PJ, Mentha $G$, et al. Hepatocyte steatosis is a cytopathic effect of hepatitis C virus genotype 3. J Hepatol 2000; 33: 106-115.

9. Boulant S, Douglas MW, Moody L, Budkowska A, TargettAdams P, McLauchlan J. Hepatitis C virus core protein induces lipid droplet redistribution in a microtubule- and dynein-dependent manner. Traffic 2008; 9: 1268-1282.

10. Shi ST, Polyak SJ, Tu H, Taylor DR, Gretch DR, Lai MM. with genotype 3 . Steatosis may persist in most patients with non-3 genotypes, even in cases of sustained virologic response.

In a recent review, Negro (38) confirmed that hepatic steatosis is more frequent and severe in $\mathrm{CHC}$ patients with genotype non-1, suggesting the interaction of viruses with lipid metabolism. Also, in the present study we observed that total serum cholesterol was lower in $\mathrm{CHC}$ patients with genotype non-1 than in patients with genotype 1, although the concentration of $\mathrm{Tg}$ was also lower in this group, but with no significant difference between them $(39,40)$.

The results of the present study have important implications. The genetic MTP $-493 \mathrm{G} / \mathrm{T}$ polymorphism in $\mathrm{CHC}$ genotype 1 patients was more frequent among subjects with higher degrees of fibrosis although the GG+GT genotypes were found to be independent protective factors against steatosis in patients with $\mathrm{CHC}$ from Brazil. Moreover, the total serum cholesterol and LDL-C concentrations were lower in patients with steatosis.

\section{Acknowledgments}

Research supported by CAPES.
Hepatitis C virus NS5A colocalizes with the core protein on lipid droplets and interacts with apolipoproteins. Virology 2002; 292: 198-210.

11. Hui JM, Kench J, Farrell GC, Lin R, Samarasinghe D, Liddle C, et al. Genotype-specific mechanisms for hepatic steatosis in chronic hepatitis C infection. J Gastroenterol Hepatol 2002; 17: 873-881.

12. Rubbia-Brandt L, Fabris P, Paganin S, Leandro G, Male PJ, Giostra E, et al. Steatosis affects chronic hepatitis C progression in a genotype specific way. Gut 2004; 53: 406412.

13. Asselah T, Boyer N, Guimont MC, Cazals-Hatem D, Tubach $\mathrm{F}$, Nahon K, et al. Liver fibrosis is not associated with steatosis but with necroinflammation in French patients with chronic hepatitis C. Gut 2003; 52: 1638-1643.

14. Schreuder TC, Verwer BJ, van Nieuwkerk CM, Mulder CJ. Nonalcoholic fatty liver disease: an overview of current insights in pathogenesis, diagnosis and treatment. World $\mathrm{J}$ Gastroenterol 2008; 14: 2474-2486.

15. Asselah T, Rubbia-Brandt L, Marcellin P, Negro F. Steatosis in chronic hepatitis C: why does it really matter? Gut 2006; 55: 123-130.

16. Okuda M, Li K, Beard MR, Showalter LA, Scholle F, Lemon $\mathrm{SM}$, et al. Mitochondrial injury, oxidative stress, and antioxidant gene expression are induced by hepatitis $\mathrm{C}$ virus core protein. Gastroenterology 2002; 122: 366-375.

17. Guo J, Friedman SL. Hepatic fibrogenesis. Semin Liver Dis 2007; 27: 413-426.

18. Miyanari $\mathrm{Y}$, Atsuzawa K, Usuda N, Watashi K, Hishiki T, Zayas $\mathrm{M}$, et al. The lipid droplet is an important organelle 
for hepatitis C virus production. Nat Cell Biol 2007; 9: 10891097.

19. Domitrovich AM, Felmlee DJ, Siddiqui A. Hepatitis $C$ virus nonstructural proteins inhibit apolipoprotein B100 secretion. J Biol Chem 2005; 280: 39802-39808.

20. Grobholz R, Hacker HJ, Thorens B, Bannasch P. Reduction in the expression of glucose transporter protein GLUT 2 in preneoplastic and neoplastic hepatic lesions and reexpression of GLUT 1 in late stages of hepatocarcinogenesis. Cancer Res 1993; 53: 4204-4211.

21. Boren J, Veniant MM, Young SG. Apo B100-containing lipoproteins are secreted by the heart. J Clin Invest 1998; 101: 1197-1202.

22. Nielsen LB, Veniant M, Boren J, Raabe M, Wong JS, Tam C, et al. Genes for apolipoprotein B and microsomal triglyceride transfer protein are expressed in the heart: evidence that the heart has the capacity to synthesize and secrete lipoproteins. Circulation 1998; 98: 13-16.

23. Mirandola S, Bowman D, Hussain MM, Alberti A. Hepatic steatosis in hepatitis $\mathrm{C}$ is a storage disease due to HCV interaction with microsomal triglyceride transfer protein (MTP). Nutr Metab 2010; 7: 13.

24. Karpe F, Lundahl B, Ehrenborg E, Eriksson P, Hamsten A. A common functional polymorphism in the promoter region of the microsomal triglyceride transfer protein gene influences plasma LDL levels. Arterioscler Thromb Vasc Biol 1998; 18: 756-761.

25. Bernard S, Touzet S, Personne I, Lapras V, Bondon PJ, Berthezene F, et al. Association between microsomal triglyceride transfer protein gene polymorphism and the biological features of liver steatosis in patients with type II diabetes. Diabetologia 2000; 43: 995-999.

26. Salgado AL, Carvalho L, Oliveira AC, Santos VN, Vieira JG, Parise ER. Insulin resistance index (HOMA-IR) in the differentiation of patients with non-alcoholic fatty liver disease and healthy individuals. Arq Gastroenterol 2010; 47: 165-169.

27. Friedewald WT, Levy RI, Fredrickson DS. Estimation of the concentration of low-density lipoprotein cholesterol in plasma, without use of the preparative ultracentrifuge. Clin Chem 1972; 18: 499-502.

28. Namikawa C, Shu-Ping Z, Vyselaar JR, Nozaki Y, Nemoto $\mathrm{Y}$, Ono $\mathrm{M}$, et al. Polymorphisms of microsomal triglyceride transfer protein gene and manganese superoxide dismutase gene in non-alcoholic steatohepatitis. J Hepatol 2004; 40: 781-786.

29. Gambino R, Cassader M, Pagano G, Durazzo M, Musso G. Polymorphism in microsomal triglyceride transfer protein: a link between liver disease and atherogenic postprandial lipid profile in NASH? Hepatology 2007; 45: 1097-1107.

30. Zampino R, Ingrosso D, Durante-Mangoni E, Capasso R, Tripodi MF, Restivo L, et al. Microsomal triglyceride transfer protein (MTP) $-493 \mathrm{G} / \mathrm{T}$ gene polymorphism contributes to fat liver accumulation in HCV genotype 3 infected patients. $J$ Viral Hepat 2008; 15: 740-746.

31. Richardson MM, Powell EE, Barrie HD, Clouston AD, Purdie DM, Jonsson JR. A combination of genetic polymorphisms increases the risk of progressive disease in chronic hepatitis C. J Med Genet 2005; 42: e45.

32. Petit JM, Masson D, Minello A, Duvillard L, Galland F, Verges $B$, et al. Lack of association between microsomal triglyceride transfer protein gene polymorphism and liver steatosis in HCV-infected patients. Mol Genet Metab 2006; 88: 196198.

33. Mirandola $\mathrm{S}$, Osterreicher $\mathrm{CH}$, Marcolongo $\mathrm{M}$, Datz $\mathrm{C}$, Aigner E, Schlabrakowski A, et al. Microsomal triglyceride transfer protein polymorphism $(-493 \mathrm{G} / \mathrm{T})$ is associated with hepatic steatosis in patients with chronic hepatitis C. Liver Int 2009; 29: 557-565.

34. Corey KE, Kane E, Munroe C, Barlow LL, Zheng H, Chung RT. Hepatitis $C$ virus infection and its clearance alter circulating lipids: implications for long-term follow-up. Hepatology 2009; 50: 1030-1037.

35. Andre P, Komurian-Pradel F, Deforges S, Perret M, Berland $\mathrm{JL}$, Sodoyer M, et al. Characterization of low- and very-lowdensity hepatitis $\mathrm{C}$ virus RNA-containing particles. J Virol 2002; 76: 6919-6928.

36. Agnello V, Abel G, Elfahal M, Knight GB, Zhang QX. Hepatitis $C$ virus and other flaviviridae viruses enter cells via low density lipoprotein receptor. Proc Natl Acad Sci U S A 1999; 96: 12766-12771.

37. Molina S, Castet V, Fournier-Wirth C, Pichard-Garcia L, Avner R, Harats D, et al. The low-density lipoprotein receptor plays a role in the infection of primary human hepatocytes by hepatitis C virus. J Hepatol 2007; 46: 411-419.

38. Negro F. Abnormalities of lipid metabolism in hepatitis $C$ virus infection. Gut 2010; 59: 1279-1287.

39. Kumar D, Farrell GC, Fung C, George J. Hepatitis C virus genotype 3 is cytopathic to hepatocytes: Reversal of hepatic steatosis after sustained therapeutic response. Hepatology 2002; 36: 1266-1272.

40. Poynard T, Ratziu V, McHutchison J, Manns M, Goodman $Z$, Zeuzem $S$, et al. Effect of treatment with peginterferon or interferon alfa- $2 \mathrm{~b}$ and ribavirin on steatosis in patients infected with hepatitis C. Hepatology 2003; 38: 75-85. 